\title{
GAC-MAC SUMMARY \\ Whitehorse 2016: GAC-MAC Joint Annual Meeting Field Trips
} FIELD GUIDE

\author{
Rosie Cobbett \\ Yukon Geological Survey \\ 91807 Alaska Highway \\ Whitehorse, Yukon Territory \\ E-mail: Rosie.Cobbett@gov.yk.ca
}

\section{FIELD TRIPS SUMMARY}

Nestled in the heart of the Northern Cordillera, Yukon's Capital Whitehorse is surrounded by diverse geology spanning the Proterozoic to present that is spectacularly exposed along our transportation system. This meeting is complimented by a full suite of field trips that will tour some of the best the Yukon and southeast Alaska has to offer geologists. Workshops include 'Indicator minerals in till and stream sediments of the Canadian Cordillera,' 'Ancient and Modern VMS deposits,' and an EdGEO Teacher Professional Development Workshop. For full details on the technical program, travel and accommodation information visit: www.whitehorse2016.ca.

The Whitehorse Copper belt provides a close to home tour through a historic mining district located only a few kilometres from the city centre. The $30 \mathrm{~km}$-long belt hosts a number of mineralized occurrences and historic mine sites. The first discoveries were made during the stampede to the Klondike between 1897 and 1899; many of these deposits were mined intermittently during a first phase of mining until 1920. A modern phase of exploration and mining took place between 1967 and 1982. The trip will include stops at heritage sites where historical mine workings give you a glimpse into the past. Visits to more modern mining and exploration sites are sure to pique your interest, where uncommon skarn minerals such as thulite, valleriite and yellow serpentine may be found. This is a very affordable way of adding value to your conference experience!

If you are looking for a multi-day adventure there are several trips that cover a range of topics from placer gold to hardrock mining. A two day trip to Faro, located north of Whitehorse, focuses on the geology of the Anvil District and remediation of the Faro Mine Complex (FMC), which is Canada's largest Acid Rock Drainage (ARD) contaminated

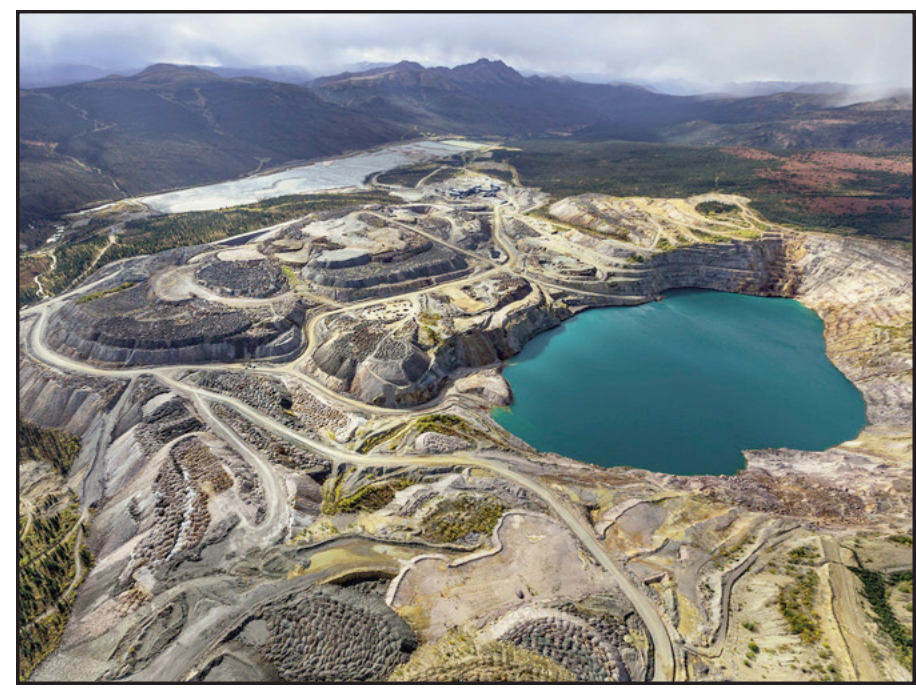

Faro Mine Complex: Canada's largest Acid Rock Drainage contaminated mine site (will be explored during the trip titled, "SED-Exhumed: Catch a rare glimpse into the belly of the Faro Mine Complex, one of Canada's most prolific past-producers of lead and zinc").

mine site. The geology portion of the trip will discuss the stratigraphy and structure of the Anvil pyritic massive sulphide deposits and their enclosing host rocks. The Cambrian Anvil deposits are situated in Selwyn basin, a lower Paleozoic marine shale basin southwest of carbonate platform rocks of northwest Laurentia. Open pit mining and on-site milling operations produced approximately 400 million tonnes of potentially acid-generating waste rock and tailings. Protecting the surrounding aquatic and terrestrial environment from these wastes and associated heavy metal-bearing seepage presents significant challenges in a mountainous, northern environment. This trip will take participants along the scenic Robert Campbell Hwy with a night's stay in the town of Faro 'Yukon's best kept Secret' located along the banks of the Pelly River.

Another two day trip will guide participants through the historic and active Keno Hill Mine, located 330 kilometres north of Whitehorse in one of the world's highest-grade silver mineralized districts. Field stops will examine host rock stratigraphy and mine sites in the district, view mineralized drill core samples and visit the historic community of Keno City. Between 1913 and 1989, the Keno Hill Silver District produced more than 214 million ounces of silver from over 4.8 


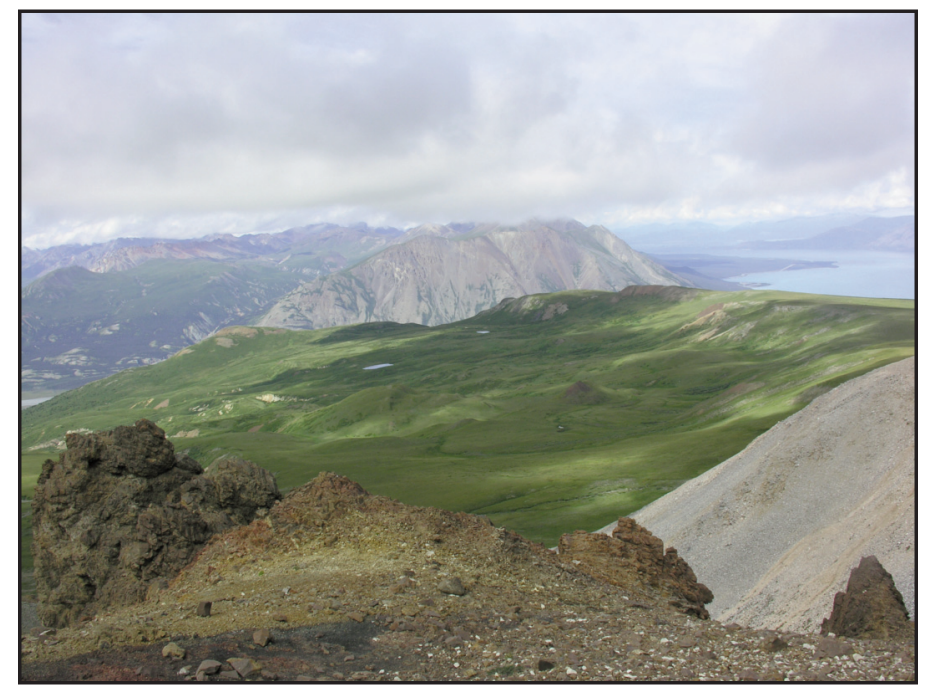

Kluane Range Mountains just north of Haines Junction: Kluane Lake in the background (will be viewed during trip titled, "Tectonics of the Intermontane and Insular terranes, and development of Mesozoic synorogenic basins in southern Yukon; Carmacks to Kluane Lake").

million tonnes of ore. There are over 35 mine sites that once contained some of the richest $\mathrm{Ag}-\mathrm{Pb}-\mathrm{Zn}$ vein deposits in the world. It provided the backbone of the Yukon economy from the 1920's until the 1960's and at one time supported up to $15 \%$ of the Territories' population. Two nights will be spent in the historic Keno city, where participants will have ample time to do the walking tour of Keno City, have a pint at the Keno City Hotel that was built in the early 1920's, or simply explore this mining ghost town.

The 'veins to valleys' field trip will take participants all the way to Dawson City and introduce them to the geology, structural evolution, geochemistry, placer deposits and Pleistocene palaeontology of the northern and central Klondike District. The route will take you into some of the most famous gold producing drainages in the world, including Bonanza and Hunker creeks, while exploring fascinating geology and modern placer mining methods. In the evenings we will stay in Dawson City and give you a taste of gold rush culture under the midnight sun. Sign up early and stake your claim on this rare field trip to the Klondike!

A five day field trip takes participant down the 'Trail of 1898 ' to Skagway, then onto Juneau and Haines via ferry, and ending with a drive through the spectacular scenery of the front ranges of the Saint Elias Mountains. This trip will expose participants to the best mineral deposits in southeast Alaska and is bookended by two days of highway stops that will put the deposits in a regional geological context. The focus will be split between volcanogenic massive sulphide deposits of the Late Triassic Alexander metallogenic belt and orogenic gold deposits of the Cretaceous Juneau Gold Belt. For a truly immersive VMS experience, this post-conference field trip can be paired with the pre-conference VMS workshop taught by world-class experts and emphasizing deposits from the northern Cordillera.

A 3-day field trip will examine the geology of the Intermontane and Insular terranes (mainly Stikinia and Wrangellia), the development of Mesozoic synorogenic basins (Whitehorse, Kluane, Dezadeash), and related Mesozoic-
Cenozoic arc magmatism between Carmacks, Whitehorse and Kluane Lake in southern Yukon. The scenic roadside and river exposures will provide the backdrop for discussions of the tectonic evolution of the northern Cordilleran orogen and its resources, from Paleozoic to the Present. This trip will involve long-distance travel on major Yukon highways and end with two short hikes in the magnificent Kluane Ranges.

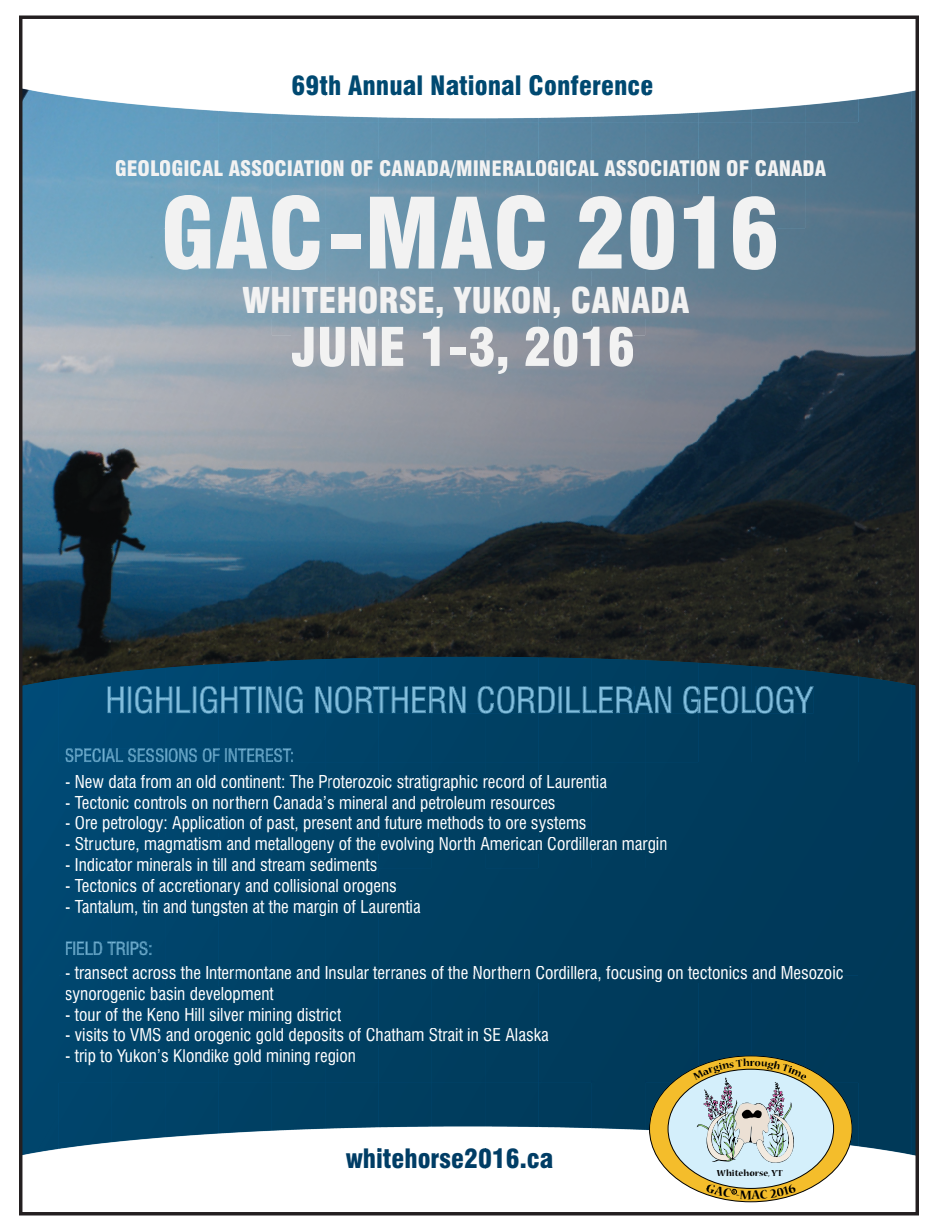

